\title{
Faktor yang Mempengaruhi Pemanfaatan Pelayanan Kesehatan Peduli Remaja (PKPR) oleh Remaja Sekolah di Wilayah Kerja Puskesmas Bondowoso
}

\section{(Factors that Affect Utilization of Adolescent Health Care Services by School Adolescents in the Work Area of Community Health Centers in Bondowoso)}

\author{
Citra Al Karina, Christyana Sandra, Yennike Tri Herawati \\ Peminatan Administrasi dan Kebijakan Kesehatan, Program Studi S1 Kesehatan Masyarakat, \\ Fakultas Kesehatan Masyarakat, Universitas Jember \\ Jl. Kalimantan No. 3768121 Jember, Jawa Timur, Indonesia \\ e-mail: citra2910@yahoo.com
}

\begin{abstract}
PKPR is a program developed since 2003 at the primary care to improve the health status of adolescence. It was implemented since 2007 in 11 health centers in Bondowoso. But, the visit utilization data in the 15-19 age was under the expected target is equal to $100 \%$. The study aimed to analyze the factors that affect the utilization PKPR by school adolescents (15-19 years) in the working area of Bondowoso's health centers in 2019. This was cross-sectional study with 96 respondents choosed by multistage sampling from Tlogosari, Tamanan and Maesan health centers. Data were obtained by questionnaire and documentation and analyzed using chi-square or fisher's exact test and logistic regression in the form forward with a significance level of $\alpha=0.05$. The results showed that there is no influence of age $(p=0.554)$; gender ( $p=0.853)$; level of education $(p=0.348)$; and knowledge $(p=0.584)$ the predisposing factors. There were no significant association of the health insurance ownership $(p=0.784)$ and accessibility to health care $(p=1.000)$; but there were significant association of the availability of health workers $(p=0.002)$ and health care $(p=0.000)$, the competence of health professionals $(p=0.002)$, and the time/speed of service $(p=0.012)$ in the enabling characteristics. Factors needs (perceived need) had no association $(p=1.000)$. The most significant factor on the utilization PKPR was the health facilities availability $(p=0.045)$ and health workers competence $(p=0.001)$.
\end{abstract}

Keywords: PKPR program, utilization PKPR, youth, access

\begin{abstract}
Abstrak
PKPR ialah program yang dikembangkan sejak 2003 di tingkat puskesmas untuk diakses oleh remaja guna meningkatkan status kesehatannya. PKPR dilaksanakan sejak 2007 pada 11 puskesmas di Kabupaten Bondowoso. Data kunjungan pemanfaatan PKPR usia 15-19 tahun belum mencapai target yang diharapkan yaitu sebesar $100 \%$. Tujuan penelitian ini untuk menganalisis faktor yang mempengaruhi pemanfaatan PKPR oleh remaja sekolah (15-19 tahun) di wilayah kerja puskesmas Kabupaten Bondowoso tahun 2019. Penelitian ini merupakan penelitian analitik dengan desain cross-sectional. Sampel penelitian 96 remaja yang diproporsikan pada Puskesmas Tlogosari, Tamanan dan Maesan dengan teknik multistage sampling. Data diperoleh melalui kuesioner dan dokumentasi. Analisis data dilakukan dengan uji chi-square, fisher's exact test dan regresi logistik berupa forward dengan tingkat signifikansi $\alpha=0,05$. Hasil penelitian menunjukkan bahwa untuk karakteristik predisposisi tidak terdapat pengaruh yaitu umur $(p=0,554)$; jenis kelamin $(p=0,853)$; tingkat pendidikan $(p=0,348)$; dan pengetahuan $(p=0,584)$. Karakteristik enabling yang tidak terdapat pengaruh yaitu kepemilikan asuransi kesehatan $(p=0,784)$ dan aksesibilitas menuju pelayanan kesehatan $(p=1,000)$; serta variabel yang terdapat pengaruh ialah ketersediaan tenaga kesehatan $(p=0,002)$ dan fasilitas
\end{abstract}


Karina, et al, Faktor Yang Mempengaruhi Pemanfaatan Pelayanan Kesehatan ......

kesehatan $(p=0,000)$, kompetensi tenaga kesehatan $(p=0,002)$, dan waktu/kecepatan pelayanan $(p=0,012)$. Faktor kebutuhan (perceived need) tidak terdapat pengaruh $(p=1,000)$. Hasil uji multivariat regresi logistik dengan metode forward stepwise (likelihood ratio) faktor yang paling berpengaruh terhadap pemanfaatan PKPR adalah tidak tersedia fasilitas kesehatan $(p=0,045)$ dan tenaga kesehatan kurang kompeten $(p=0,001)$.

Kata Kunci: program PKPR, pemanfaatan PKPR, remaja, akses

\section{Pendahuluan}

Masa remaja ialah masa peralihan seseorang dari anak-anak menuju dewasa bukan hanya secara fisik melainkan juga psikologis, biologis dan intelektual [1,2]. Masa remaja ini berada pada kelompok usia antara 10-19 tahun yang terbagi menjadi kelompok remaja awal (10-14 tahun) dan remaja lanjutan (15-19 tahun) yang diperkirakan sebesar $18 \%$ dari jumlah penduduk dunia [1,3]. Jumlah penduduk Indonesia tahun 2018 pada usia 10-19 tahun sebanyak 45.121 .53 jiwa, dengan jumlah laki-laki 23.110.733 jiwa dan perempuan 22.010.820 jiwa [4].

Remaja Indonesia menghadapi berbagai tantangan seperti perilaku berisiko, meliputi $8 \%$ pria dan $2 \%$ wanita pernah melakukan hubungan seksual pranikah; $45 \%$ pria dan $1 \%$ wanita merokok; $26 \%$ pria dan $3 \%$ wanita pada usia 15-18 tahun mengkonsumsi minuman beralkohol; dan $4 \%$ pria umur $15-24$ tahun mengkonsumsi obat-obatan terlarang [5]. Situasi kesehatan remaja di Jawa Timur tahun 2018 , yaitu $1,61 \%$ pria dan $0,03 \%$ wanita merokok tembakau setiap hari; $0,6 \%$ konsumsi minuman beralkohol; pada usia $\geq$ 15 tahun 4,8\% mengalami depresi dan $7,2 \%$ mengalami gangguan mental emosional; serta $55,8 \%$ pria dan $52,2 \%$ wanita tahu mengenai resiko kehamilan setelah sekali melakukan hubungan seksual [4]. Situasi kesehatan remaja di Kabupaten Bondowoso tahun 2019 yaitu 395 mengalami masalah menstruasi, 65 masalah kehamilan, 1 kasus infeksi menular seksual, 25 pria dan 5 wanita mengkonsumsi minuman beralkohol, 20 pria menggunakan narkotika, 44 pria dan 46 wanita penderita HIV, 22 pria penderita malaria, dan 6 pria penderita TBC [6].

Kondisi kesehatan remaja yang demikian, perlu adanya upaya pemberian informasi, edukasi, serta pelayanan yang tepat dan sesuai untuk mengurangi dan menyelesaikan masalah kesehatan pada remaja. Maka dari itu, pada tahun 2003 Kementerian Kesehatan RI mencanangkan program khusus kesehatan remaja yang dikenal sebagai Pelayanan Kesehatan Peduli Remaja (PKPR). PKPR ialah suatu program yang dikembangkan di tingkat puskesmas yang ditujukan serta untuk diakses oleh remaja guna meningkatkan status kesehatan remaja (Kemenkes RI, 2018:140). Penyelenggaraannya berkaitan dengan 5 aspek pendukung dalam Standar Nasional PKPR, yaitu sumber daya manusia kesehatan, fasilitas kesehatan, remaja, jejaring, dan manajemen kesehatan [7].

Jumlah puskesmas PKPR di Indonesia tahun 2018 sebanyak 6.204 unit yang tersebar di 34 provinsi. Jumlah puskesmas penyelenggaraan PKPR di provinsi Jawa Timur pada tahun 2018454 unit $(46,95 \%)$ yang telah melebihi target Renstra tahun 2018 sebesar 40\% ${ }^{[4]}$. Berdasarkan data dari Seksi Kesehatan Keluarga dan Gizi Masyarakat Dinas Kesehatan Kabupaten Bondowoso pada bulan November 2018, didapatkan bahwa program PKPR dilaksanakan sejak tahun 2007 pada 11 puskesmas di Kabupaten Bondowoso dan telah strata, sehingga pada tahun 2017 dilakukan evaluasi dan pembentukan tim baru hingga terwujudnya 25 puskesmas penyelenggara PKPR. Strata program PKPR yaitu paripurna Puskesmas Tlogosari; optimal Puskesmas Grujugan, Tamanan, Kotakulon, dan Kademangan; serta 20 puskesmas lainnya ialah strata minimal [6].

Data kunjungan pemanfaatan PKPR di Kabupaten Bondowoao dari bulan Januari hingga Desember 2019 pada remaja usia 15-19 tahun sebanyak 35.832 jiwa. Persentase pemanfaatan Komunikasi, Informasi dan Edukasi (KIE) sebesar $14,26 \% \quad(5.110 \quad$ remaja); pelayanan kesehatan sebesar $76,75 \% \quad(27.500$ remaja); dan konseling sebesar 1,71\% (614 remaja). Capaian dalam pemanfaatan PKPR pada remaja sekolah usia ini adalah 
Karina, et al, Faktor Yang Mempengaruhi Pemanfaatan Pelayanan Kesehatan ......

33.224 remaja $(92,72 \%)$, masih belum mencapai target yang diharapkan yaitu sebesar $100 \%$ [6]. Capaian pemanfaatan yang belum memenuhi target dan pelaksanaan yang belum optimal menjadi alasan Kabupaten Bondowoso sebagai wilayah penelitian. Selain itu, pelaksanaan program PKPR masih belum maksimal dikarenakan petugas merangkap program lainnya, petugas sering menjalankan kegiatan di lapangan, dan belum semua memiliki ruang khusus PKPR [8].

Upaya guna meningkatkan akses remaja terhadap pelayanan kesehatan dasar terutama dalam kegiatan PKPR, sangat penting bagi puskesmas dan jaringannya di pelayanan tingkat pertama [9]. Sehingga akses remaja dalam memanfaatkan PKPR menjadi penentu berjalannya atau tidak program tersebut. Menurut Anderson (1960), ada tiga kategori utama dalam pemanfaatan pelayanan kesehatan, yaitu karakteristik predisposisi (usia, jenis kelamin, status perkawinan, jumlah keluarga, pendidikan, kesukuan dan kepercayaan akan kesehatan); karakteristik pemungkin (kepemilikan asuransi kesehatan, aksesibilitas, penghasilan keluarga, kemampuan membeli jasa pelayanan kesehatan, ketersediaan tenaga kesehatan, ketersediaan fasilitas kesehatan, keterampilan tenaga kesehatan, dan waktu/kecepatan pelayanan); dan faktor kebutuhan (perceived need dan evakuated need) [10]. Menurut SN-PKPR (2014) menyatakan bahwa PKPR terdiri dari 5 aspek penyelenggaraan, yaitu SDM, fasilitas kesehatan, remaja, dukungan jejaring, dan manajemen kesehatan [7].

Variabel yang menjadi penelitian ialah karakteristik predisposisi (umur, jenis kelamin, tingkat pendidikan dan pengetahuan). Karakteristik pemungkin (kepemilikan asuransi kesehatan, aksesibilitas menuju pelayanan kesehatan, ketersediaan tenaga dan fasilitas kesehatan, waktu/kecepatan pelayanan, serta kompetensi tenaga kesehatan). Serta karakteristik kebutuhan (penilaian keadaan yang dirasakan oleh individu). Sehinggan tujuan dari penelitian ini ialah untuk menganalisis faktor yang mempengaruhi pemanfaatan PKPR oleh remaja sekolah (15-19 tahun) di wilayah kerja puskesmas di Kabupaten Bondowoso tahun 2019.

\section{Metode Penelitian}

Jenis penelitian dalam penelitian ini ialah analitik dengan menggunakan desain cross sectional. Penelitian dilakukan di tiga wilayah kerja puskesmas yaitu Puskesmas Tlogosari, Tamanan dan Maesan Kabupaten Bondowoso. Penelitian dilakukan pada bulan Agustus hingga September 2019. Populasi dalam penelitian ini ialah seluruh remaja yang berusia 15-19 tahun di tiga wilayah kerja puskesmas yaitu sebanyak 8.843 remaja. Sampel penelitian didapatkan dengan menggunakan rumus Slovin (1960) sebanyak 96 remaja yang diproporsikan pada masing-masing wilayah kerja puskesmas dengan teknik multistage sampling (sampling bertingkat/bertahap), yaitu Puskesmas Tlogosari 35 remaja, Puskesmas Tamanan 27 remana, dan Puskesmas Maesan 34 remaja. Kriteria eksklusi dalam penelitian ini adalah siswa yang menjadi kader remaja tidak dapat berpartisipasi dalam penelitian. Pengumpulan data dilakukan dengan melalui angket/kuesioner dan studi dokumentasi. Peneliti telah melakukan uji coba angket/kuesioner kepada 30 remaja di wilayah kerja Puskesmas Grujugan Kabupaten Bondowoso. Analisis data dilakukan secara uji statistik univariat, bivariat menggunakan uji chi-square atau fisher's exact test dan multivariat menggunakan uji regresi logistik berupa forward dengan tingkat signifikansi $\alpha=$ 0,05 .

\section{Hasil Penelitian}

\section{Analisis Bivariat}

Tabel 1. Tabulasi Silang antara Karakteristik Predisposisi dengan Pemanfaatan PKPR

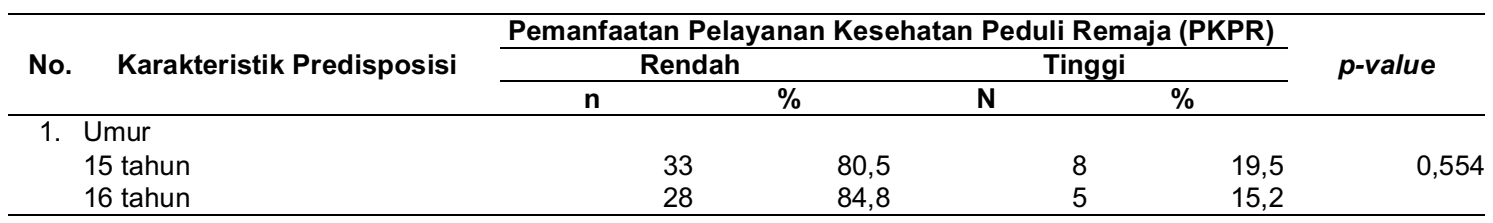


Karina, et al, Faktor Yang Mempengaruhi Pemanfaatan Pelayanan Kesehatan ......

\begin{tabular}{|c|c|c|c|c|c|c|}
\hline & 17 tahun & 14 & 93,3 & 1 & 2,5 & \\
\hline & 18 tahun & 5 & 71,4 & 2 & 28,6 & \\
\hline & Total & 80 & 83,3 & 16 & 16,7 & \\
\hline \multirow[t]{4}{*}{2.} & Jenis Kelamin & & & & & \\
\hline & Perempuan & 47 & 83,9 & 9 & 16,1 & 0,853 \\
\hline & Laki-laki & 33 & 82,5 & 7 & 17,5 & \\
\hline & Total & 80 & 83,3 & 16 & 16,7 & \\
\hline \multirow[t]{4}{*}{3} & Tingkat Pendidikan & & & & & \\
\hline & Menengah & 61 & 85,9 & 10 & 14,1 & 0,348 (fisher's \\
\hline & Rendah & 19 & 76,0 & 6 & 24,0 & $\begin{array}{r}\text { exact } \\
\text { test) }\end{array}$ \\
\hline & Total & 80 & 83,3 & 16 & 16,7 & \\
\hline \multirow[t]{4}{*}{4.} & Pengetahuan & & & & & \\
\hline & Tinggi & 25 & 78,1 & 7 & 21,9 & 0,333 \\
\hline & Rendah & 55 & 85,1 & 9 & 14,1 & \\
\hline & Total & 80 & 83,3 & 16 & 16,7 & \\
\hline
\end{tabular}

Berdasarkan tabel 1. dapat diketahui bahwa mayoritas pemanfaatan PKPR rendah sebesar $83,3 \%$ yaitu rata-rata berumur 15 tahun (33 responden), jenis kelamin perempuan (47 responden), tingkat pendidikan menengah (61 responden) dan pengetahuan rendah (55 responden). Hasil uji chi-square atau fisher exact test pada keempat variabel dalam karakteristik predisposisi (umur, jenis kelamin, tingkat pendidikan dan pengetahuan) tidak terdapat pengaruh yang bermakna dengan pemanfaatan PKPR dengan nilai $p$-value lebih besar dari $0,05(p>0,05)$.

Tabel 2. Tabulasi Silang antara Karakteristik Pemungkin dengan Pemanfaatan PKPR

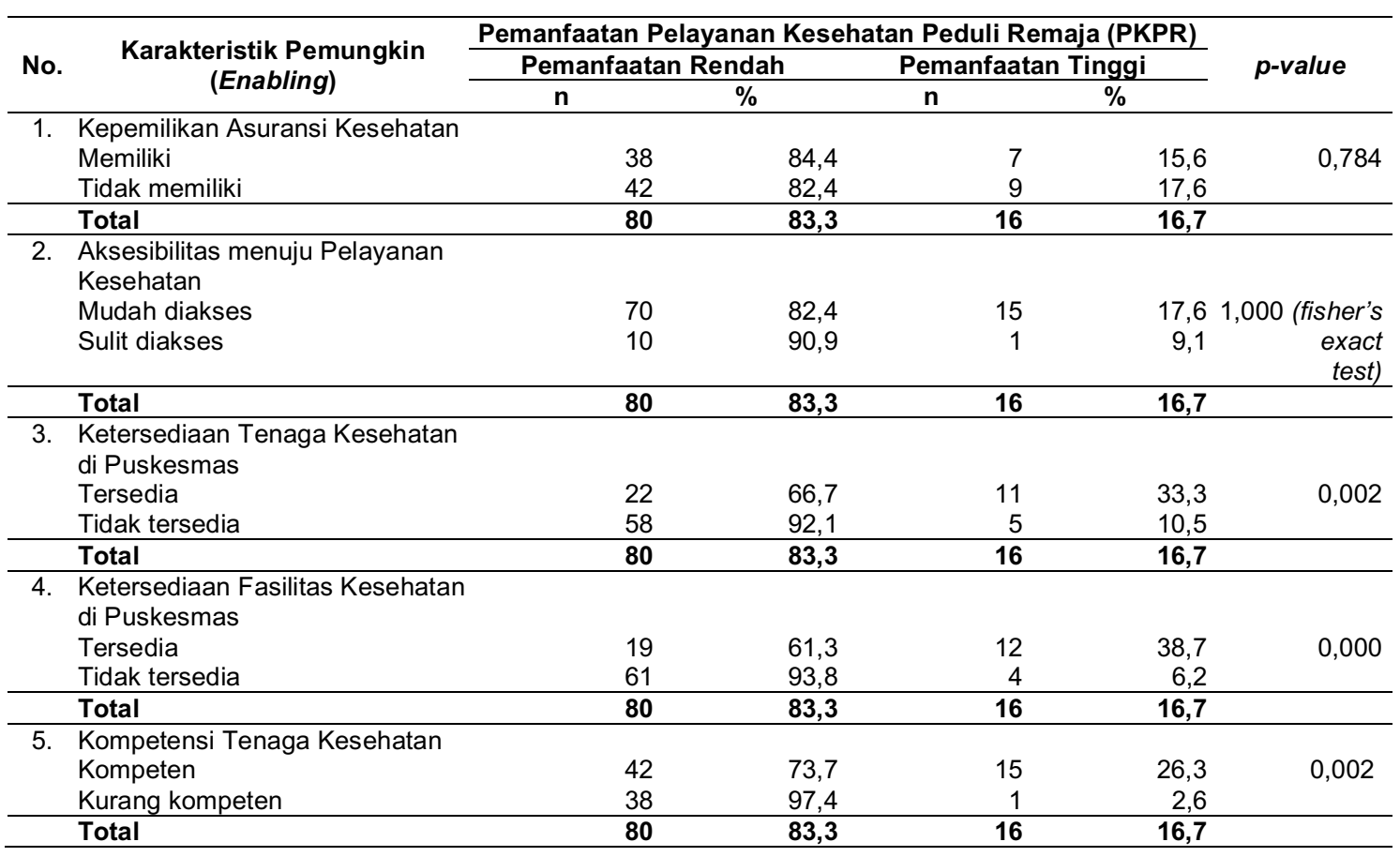

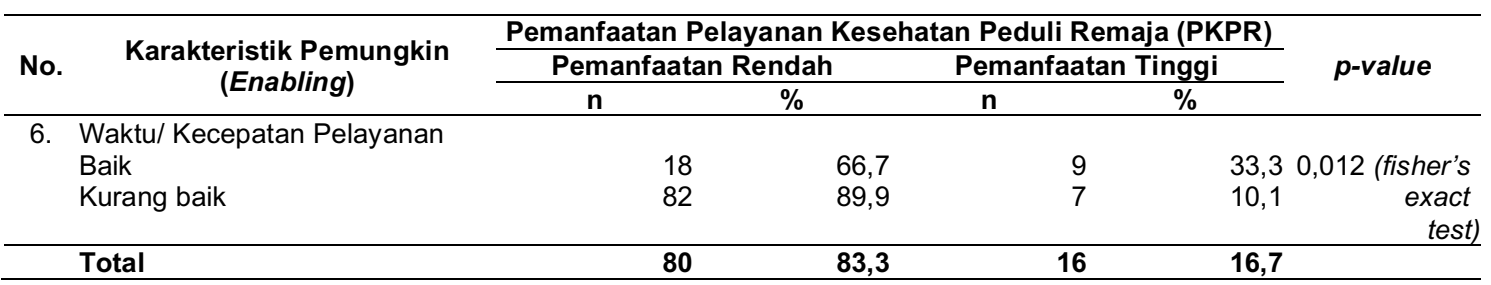


Karina, et al, Faktor Yang Mempengaruhi Pemanfaatan Pelayanan Kesehatan ......

Berdasarkan tabel 2. dapat diketahui bahwa mayoritas pemanfaatan PKPR rendah sebesar $83,3 \%$ (80 responden) yaitu tidak memiliki asuransi kesehatan (42 responden), aksesibilitas menuju pelayanan kesehatan mudah (70 responden), tidak tersedia tenaga kesehatan (58 responden), tidak tersedia fasilitas kesehatan di puskesmas (61 responden), tenaga kesehatan dinilai kompeten (42 responden), dan kurang baiknya waktu/kecepatan pelayanan (82 responden). Hasil uji chisquare atau fisher exact test pada variabel dalam karakteristik pemungkin dengan nilai $p$-value variabel kepemilikan asuransi
$(0,784)$ dan aksesibilitas menuju pelayanan $(1,000)$, berarti lebih dari $0,05(p>0,05)$ atau tidak terdapat pengaruh yang bermakna dengan pemanfaatan PKPR. Sedangkan nilai $p$-value pada variabel ketersediaan tenaga kesehatan $(0,002)$, ketersediaan fasilitas kesehatan di puskesmas $(0,000)$, kompetensi tenaga kesehatan $(0,002)$, dan waktu/kecepatan pelayanan $(0,012)$; yaitu kurang dari 0,05 ( $p$ $<0,05$ ) yang berarti terdapat pengaruh yang bermakna dengan pemanfaatan PKPR oleh remaja sekolah (15-19 tahun) di wilayah kerja puskesmas di Kabupaten Bondowoso tahun 2019.

Tabel 3. Tabulasi Silang antara Karakteristik Kebutuhan dengan Pemanfaatan PKPR

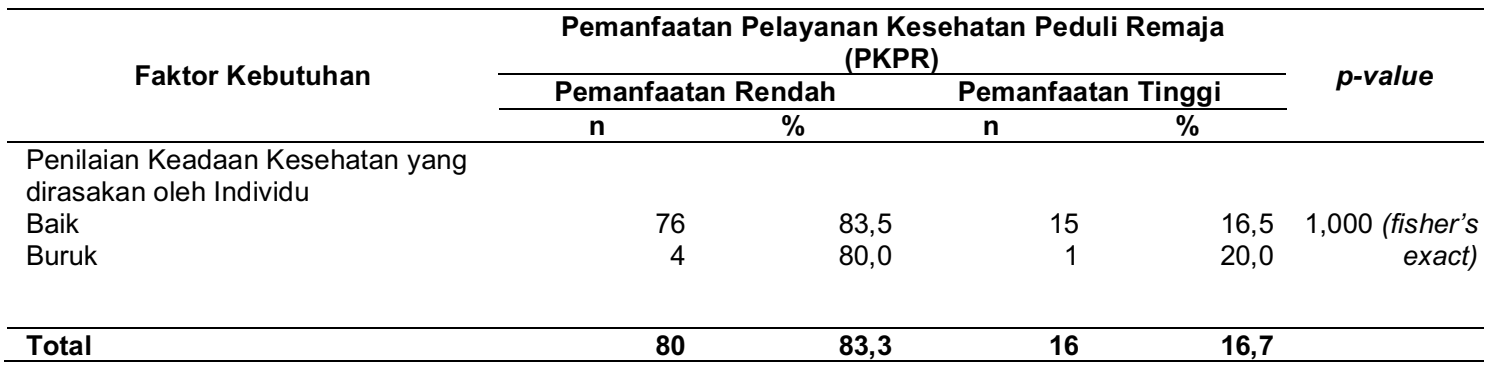

Berdasarkan tabel 3. mayoritas responden dalam penilaian keadaan yang dirasakan dalam kategori baik terdapat 76 responden $(83,5 \%)$ dengan pemanfaatan PKPR rendah. Hasil uji fisher exact test diperoleh nilai $p$-value sebesar 1,000 atau nilai $p>0,05$, dengan demikian berarti tidak

\section{Analisis Multivariat}

Tabel 4. Hasil Analisis Variabel Bebas dengan Pemanfaatan PKPR menggunakan Regresi Logistik Metode Forward Stepwise (Likelihood Ratio) pada step 2

\begin{tabular}{|c|c|c|c|}
\hline Koefisien & $p$-value & OR & $95 \% \mathrm{Cl}$ \\
\hline $\begin{array}{l}\text { Step } 1 \\
\text { Kompetensi tenaga kesehatan }\end{array}$ & & & \\
\hline $\begin{array}{l}\text { Kurang kompeten } \\
\text { Step } 2\end{array}$ & 11,717 & 2,800 & $1,553-5,049$ \\
\hline $\begin{array}{l}\text { Ketersedian fasilitas kesehatan } \\
\text { Tidak tersedia } \\
\text { Kmpetensi tenaga kesehatan }\end{array}$ & 0,045 & 0,273 & $0,077-0,970$ \\
\hline urang kompeten & 11,247 & 6,133 & $2,125-17,70$ \\
\hline $\begin{array}{l}\text { Berdasarkan tabel 4. pada hasil uji } \\
\text { multivariat menggunakan regresi logistik } \\
\text { dengan metode Forward Stepwise } \\
\text { (Likelihood Ratio) pada step 2, dapat } \\
\text { diketahui bahwa variabel yang memiliki } p \text { - } \\
\text { value <0,05 adalah ketersediaan fasilitas } \\
\text { kesehatan dan kompetensi tenaga } \\
\text { kesehatan. Tabel diatas juga menyajikan } \\
\text { nilai OR atau besaran risiko terjadinya }\end{array}$ & \multicolumn{3}{|c|}{$\begin{array}{l}\text { suatu kejadian. Fasilitas kesehatan tidak } \\
\text { tersedia memiliki nilai OR sebesar } 0,273 \\
\text { yang berarti bersifat protektif dengan nilai } \\
\text { signifikansi } 0,045 \text { (karena OR < } 1 \text { ), } \\
\text { sedangkan tenaga kesehatan kurang } \\
\text { kompeten memiliki nilai OR sebesar } 6,133 \\
\text { yang berarti } 6,1 \text { kali lipat menyebabkan } \\
\text { pemanfaatan PKPR rendah dengan nilai } \\
\text { signifikansi } 0,001 \text {. Hal ini menunjukkan }\end{array}$} \\
\hline
\end{tabular}


Karina, et al, Faktor Yang Mempengaruhi Pemanfaatan Pelayanan Kesehatan ......

bahwa variabel tersebut merupakan faktor yang paling mempengaruhi pemanfaatan PKPR oleh remaja sekolah (15-19 tahun) di wilayah kerja puskesmas Kabupaten Bondowoso tahun 2019.

\section{Pembahasan}

\section{Pengaruh Umur dengan Pemanfaatan PKPR}

Umur merupakan lama waktu yang dilalui seseorang mulai dari lahir hingga dilakukan penelitian ini dalam hitungan tahun. Berdasarkan hasil penelitian ini menunjukkan bahwa sebagian banyak responden berumur 15 tahun $(42,7 \%)$ serta 16 tahun $(34,4 \%)$ yang merupakan remaja SMP/sederajat dan SMA/sederajat. Mayoritas pemanfaatan PKPR rendah sebesar $83,3 \%$ (80 responden). Hasil uji statistik chi-square terhadap umur dengan pemanfaatan pelayanan kesehatan peduli remaja (PKPR) oleh remaja sekolah (15-19 tahun) di wilayah kerja Puskesmas Tlogosari, Tamanan dan Maesan Kabupaten Bondowoso tahun 2019 pada penelitian ini menunjukkan bahwa kedua variabel tersebut tidak terdapat pengaruh yang bermakna karena $p$-value sebesar 0,554 atau $p>0,05$ dengan tingkat kepercayaan sebesar $95 \%$. Hasil penelitian ini tidak sesuai dengan hipotesis yang ditetapkan.

Penelitian ini sejalan dengan penelitian yang dilakukan oleh Laili et al. (2019:427) faktor-faktor yang berhubungan dengan praktik pemanfaatan PKPR oleh remaja di wilayah kerja Puskesmas Bandarharjo Kota Semarang, menunjukkan hasil bahwa tidak terdapat berhubungan antara usia remaja dengan praktik pemanfaatan PKPR oleh remaja $(p=$ 0,778 ). Hal ini disebabkan karena pada umumnya responden merupakan kelompok usia remaja lanjutan (15-19 tahun), dengan demikian karakteristik responden hampir homogen sehingga faktor usia tidak berhubungan dengan praktik PKPR. Kesesuaian penelitian ini dengan penelitian sebelumnya disebabkan karena pada faktor usia yang paling muda merupakan yang paling banyak pada kategori pemanfaatan PKPR rendah. Dalam penelitian ini, ditemukan bahwa umur 15 dan 16 tahun lebih banyak dibandingkan dengan umur lainnya. Hasil penelitian ini terdapat 80 responden yang termasuk dalam pemanfaatan PKPR rendah, 33 responden diantaranya umur 15 tahun.

$\begin{array}{llr}\text { Berdasarkan hasil penyebaran } \\ \text { angket/kuesioner, } & \text { sebagian besar } \\ \text { responden yang } & \text { termasuk dalam }\end{array}$ pemanfaatan PKPR rendah dan tinggi ialah usia 15 dan 16 tahun. Umur tersebut lebih banyak yang termasuk dalam pemanfaatan rendah disebabkan mereka belum banyak yang memanfaatkan PKPR di puskesmas selain pelayanan medis (berobat) pada 2 bulan yang lalu. Mereka memanfaatkan UKS di sekolah paling banyak lebih dari 2 bulan yang lalu, sehingga hal ini menyebabkan pemanfaatan PKPR berada pada kategori rendah dalam penelitian ini.

\section{Pengaruh Jenis Kelamin dengan Pemanfaatan PKPR}

Jenis kelamin adalah karakteristik yang digunakan untuk membedakan lakilaki dan perempuan berdasarkan ciri fisik ataupun biologis dari individu tersebut. Menurut Bart Smet (1994) (dalam Muzaham, 2007:72) menyatakan bahwa perempuan lebih banyak melaporkan adanya gejala sakit dan berkonsultasi dengan dokter lebih sering daripada lakilaki. Berdasarkan hasil penelitian ini menunjukkan bahwa paling banyak responden berjenis kelamin perempuan sebanyak 56 responden $(58,3 \%)$ namun hanya 9 responden $(16,1 \%)$ yang termasuk pemanfaatan tinggi, sedangkan laki-laki hanya 7 responden.

Hasil uji statistik chi-square terhadap jenis kelamin dengan pemanfaatan pelayanan kesehatan peduli remaja (PKPR) oleh remaja sekolah (15-19 tahun) di wilayah kerja Puskesmas Tlogosari, Tamanan dan Maesan Kabupaten Bondowoso tahun 2019 pada penelitian ini menunjukkan bahwa kedua variabel tersebut tidak terdapat pengaruh yang bermakna karena $p$-value sebesar 0,853 atau $p>0,05$. Penelitian ini sejalan dengan penelitian dari Laili et al. (2019:427) faktorfaktor yang berhubungan dengan praktik pemanfaatan PKPR oleh remaja di wilayah kerja Puskesmas Bandarharjo Kota Semarang, menunjukkan hasil bahwa variabel jenis kelamin tidak berhubungan dengan praktik pemanfaatan PKPR di Puskesmas Bandarharjo Kota Semarang ( $p$ $=0,591)$. Hasil penelitian ini juga sejalan dengan penelitian yang dilakukan oleh Kristina (2017:65) di Kota Jayapura menunjukkan hasil bahwa $p$-value $=0,067$ 
atau $p>0,05$, artinya tidak terdapat hubungan antara jenis kelamin dengan pemanfaatan pelayanan kesehatan reproduksi remaja di Kota Jayapura. Hal ini disebabkan karena sebagian besar responden berjenis kelamin laki-laki, namun jenis kelamin perempuan lebih banyak tidak memanfaatkan pelayanan KRR. Sedangkan dalam penelitian ini sebagian banyak responden berjenis kelamin perempuan dan tidak memanfaatkan PKPR atau pemanfaatan PKPR rendah.

\section{Pengaruh Pendidikan dengan Pemanfaatan PKPR}

Tingkat pendidikan yang dinilai berdasarkan pernyataan responden tentang jenjang pendidikan formal yang sedang dijalankan sampai dilakukan penelitian ini. Berdasarkan hasil dari penelitian ini menyatakan bahwa sebagian besar responden berpendidikan menengah (SMA/sederajat) sebanyak 71 responden $(74,0 \%)$, sebanyak 61 responden termasuk kategori rendah dalam memanfaatkan PKPR.

Hasil uji statistik fisher's exact test terhadap tingkat pendidikan dengan pemanfaatan pelayanan kesehatan peduli remaja (PKPR) oleh remaja sekolah (15-19 tahun) di wilayah kerja Puskesmas Tlogosari, Tamanan dan Maesan Kabupaten Bondowoso tahun 2019 pada penelitian ini menunjukkan bahwa kedua variabel tersebut tidak terdapat pengaruh yang bermakna karena $p$-value sebesar 0,348 atau $p>0,05$. Hasil ini sejalan dengan penelitian yang dilakukan oleh Laili et al. (2019:427) terkait faktor-faktor yang berhubungan dengan praktik pemanfaatan PKPR oleh remaja di wilayah kerja Puskesmas Bandarharjo Kota Semarang, menunjukkan hasil bahwa variabel pendidikan terakhir responden tidak berhubungan dengan praktik pemanfaatan PKPR di Puskesmas Bandarharjo Kota Semarang $(p=0,075)$.

Tidak adanya pengaruh antara tingkat pendidikan dengan pemanfaatan PKPR pada penelitian ini dikarenakan bahwa berdasarkan hasil penyebaran angket/kuesioner sebagian besar responden menyebutkan pelayanan kesehatan peduli remaja (PKPR) yang ada di sekolah sudah cukup daripada harus datang ke puskesmas. Sehingga dalam penelitian ini, responden yang berpendidikan sedang/menengah lebih banyak yang termasuk dalam pemanfaatan PKPR rendah. Namun responden yang berpendidikan rendah juga terdapat responden yang termasuk pemanfaatan PKPR rendah.

\section{Pengaruh Pengetahuan dengan Pemanfaatan PKPR}

Pengetahuan dalam penelitian ini merupakan pemahaman responden mengenai PKPR yang meliputi: keberadaan PKPR, pengertian PKPR, tujuan PKPR, sasaran PKPR, jenis kegiatan PKPR dan informasi pelayanan kesehatan yang dibutuhkan. Berdasarkan hasil penelitian ini menunjukkan bahwa sebagian besar responden memiliki pengetahuan yang rendah sebesar 64,7\% (64 responden). Responden yang memiliki pengetahuan rendah mengenai PKPR ialah responden yang pemanfaatan PKPR rendah lebih besar dibandingkan yang pemanfaatan tinggi.

Hasil uji statistik chi-square terhadap pengetahuan dengan pemanfaatan pelayanan kesehatan peduli remaja (PKPR) oleh remaja sekolah (15-19 tahun) di wilayah kerja Puskesmas Tlogosari, Tamanan dan Maesan Kabupaten Bondowoso tahun 2019 pada penelitian ini menunjukkan bahwa kedua variabel tersebut tidak terdapat pengaruh yang bermakna karena $p$-value sebesar 0,333 atau $p>0,05$. Hasil penelitian ini sejalan dengan penelitian yang dilakukan oleh Ruwayda et al. (2017:118) menyatakan bahwa tidak ada hubungan antara pengetahuan dengan pemanfaatan pelayanan kesehatan reproduksi oleh remaja di SMPN 19 wilayah kerja Puskesmas Aur Duri Kota Jambi $(p=0,570)$. Hal ini disebabkan karena pengetahuan remaja tentang kesehatan reproduksi masih kurang dimana ibu yang telah melangsungkan pernikahan usia dini sebelumnya kurang memahami dampak dari pernikahan yang berlangsung cepat.

Hasil penelitian ini tidak sesuai dengan penelitian sebelumnya bahwa berdasarkan hasil penyebaran angket/ kuesioner sebagian besar responden berepengetahuan rendah. Hal ini dikarenakan bahwa sebagian besar responden mengetahui keberadaan puskesmas dan mendapat informasi tentang PKPR dari guru dan petugas kesehatan yang melakukan penyuluhan di sekolah, namun responden tidak 
Karina, et al, Faktor Yang Mempengaruhi Pemanfaatan Pelayanan Kesehatan ......

mengetahui bentuk kegiatan pelayanan PKPR, sasarannya siapa dan tujuannya apa secara benar sehingga mempengaruhi perilaku pemanfaatan pelayanan kesehatan di puskesmas. Pemanfaatan rendah terhadap kegiatan PKPR dikarenakan responden hanya mengetahui terkait pelayanan berobat (medis) di puskesmas. Sedangkan kegiatan PKPR di sekolah yang diketahui ialah UKS, SBH, tablet tambah darah, dan penjaringan kesehatan (suntikan).

\section{Pengaruh Kepemilikan Asuransi Kesehatan dengan Pemanfaatan PKPR Asuransi kesehatan sangatlah penting dalam pemeliharaan kesehatan masyarakat ketika sakit, bila seseorang sakit akan membutuhkan pelayanan kesehatan yang memadai dan pembiayaan kesehatan yang terjamin. Berdasarkan hasil penelitian ini menunjukkan bahwa paling banyak responden tidak memiliki asuransi kesehatan sebesar 53,1\% (51 responden). Hasil uji statistik chi-square terhadap kepemilikan asuransi kesehatan terhadap pelayanan kesehatan peduli remaja (PKPR) oleh remaja sekolah (15-19 tahun) di wilayah kerja Puskesmas Tlogosari, Tamanan dan Maesan Kabupaten Bondowoso tahun 2019 pada penelitian ini menunjukkan bahwa kedua variabel tersebut tidak terdapat pengaruh yang bermakna karena $p$-value sebesar 0,784 atau $p>0,05$. \\ Hasil penelitian tidak sesuai dengan teori pemanfaatan pelayanan kesehatan dari Andersen (1975) (dalam Muzaham, 2007:57), menyatakan bahwa faktor enabling (asuransi kesehatan) dipergunakan untuk mengetahui sejauh mana kemauan dan kemampuan responden mempergunakannya untuk pelayanan kesehatan. Asuransi dan jaminan kesehatan dapat meningkatkan demand terhadap pelayanan kesehatan, sehingga hubungan keduanya bersifat positif. Ketidaksesuaian ini terjadi karena dari 45 responden yang memiliki asuransi kesehatan namun hanya 7 responden yang memanfaatkan PKPR.}

\section{Pengaruh Aksesibilitas menuju Pelayanan Kesehatan dengan Pemanfaatan PKPR}

Aksesibilitas menuju pelayanan kesehatan dalam penelitian ini merupakan kemudahan akses responden untuk mencapai fasilitas kesehatan dinilai dari kemudahan transportasi, jarak dan waktu tempuh untuk mencapai fasilitas pelayanan, serta keterjangkauan biaya. Berdasarkan hasil penelitian ini menunjukkan bahwa mayoritas responden menilai aksesibilitas menuju pelayanan kesehatan dengan kategori mudah diakses yaitu sebanyak 85 responden (88,5\%). Hasil uji statistik fisher's exact test terhadap aksesibilitas menuju pelayanan kesehatan dengan pemanfaatan pelayanan kesehatan peduli remaja (PKPR) oleh remaja sekolah (15-19 tahun) di wilayah kerja Puskesmas Tlogosari, Tamanan dan Maesan Kabupaten Bondowoso taun 2019 pada penelitian ini menunjukkan bahwa kedua variabel tersebut tidak terdapat pengaruh yang bermakna karena $p$-value sebesar 0,684 atau $p>0,05$.

Hasil penelitian ini sejalan dengan penelitian yang dilakukan oleh Kristina (2017:65) menyatakan bahwa tidak terdapat hubungan antara jarak dengan pemanfaatan pelayanan kesehatan reproduksi remaja di Kota Jayapura. Hasil ini sejalan dengan penelitian sebelumnya dari Laili et al. (2019:426) yang menunjukkan bahwa tidak terdapat hubungan antara akses menuju pelayanan kesehatan dengan praktik pemanfaatan PKPR oleh remaja di wilayah hasil kerja Puskesmas Bandarharjo Kota Semarang dengan nilai $p$-value sebesar 0,238 .

Hasil penelitian dengan penelitian sebelumnya sesuai dengan teori yang dikemukan oleh Azwar (2010), yaitu pelayanan kesehatan yang baik adalah pelayanan yang terjangkau (affordable) oleh masyaarakat, dimana diupayakan biaya pelayanan tersebut sesuai dengan kemampuan ekonomi masyarakat. Berdasarkan hasil penyebaran angket/ kuesioner sebagian besar responden yang pemanfaatan PKPR nya rendah menyatakan akses jalan menuju puskesmas mudah, menggunakan kendaraan pribadi dengan jarak tempuh 1 $5 \mathrm{~km}$ dalam waktu 15 - 30 menit, serta mengeluarkan biaya transportasi lebih dari Rp 10.000,-. Hal ini dapat menyebabkan proporsi pemanfaatan PKPR menjadi lebih kecil dibandingkan sebaliknya.

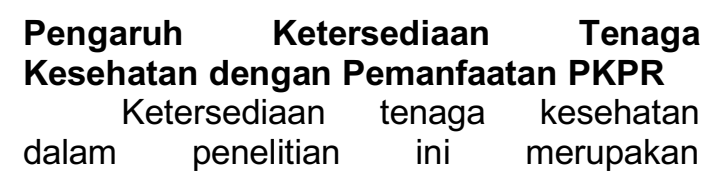


Karina, et al, Faktor Yang Mempengaruhi Pemanfaatan Pelayanan Kesehatan ......

pemahaman responden terhadap

ketersediaan tenaga kesehatan di

puskesmas (PKPR) yang dapat

memberikan pelayanan kesehatan peduli remaja yang dibutuhkan remaja, meliputi tenaga khusus PKPR, dokter, gizi, kesehatan reproduksi (IMS dan HIV), NAPZA, dan promosi kesehatan. Berdasarkan hasil penelitian ini menunjukkan bahwa sebagian besar responden menilai tidak tersedia terhadap ketersediaan tenaga kesehatan sebesar $65,6 \%$ (63 responden). Hasil uji statistik chisquare terhadap ketersediaan tenaga kesehatan dengan pemanfaatan pelayanan kesehatan peduli remaja (PKPR) oleh remaja sekolah (15-19 tahun) di wilayah kerja Puskesmas Tlogosari, Tamanan dan Maesan Kabupaten Bondowoso tahun 2019 pada penelitian ini menunjukkan bahwa kedua variabel tersebut terdapat pengaruh yang bermakna karena $p$-value sebesar 0,002 atau $p<0,05$.

Hasil ini sejalan dengan penelitian Suhariati (2010) menyatakan bahwa sumberdaya merupakan faktor yang paling berpengaruh terhadap keberhasilan implementasi program PKPR $(p=0,002)$. Hal ini dikarenakan adanya pengaruh antara ketersediaan tenaga kesehatan dengan pemanfaatan PKPR pada penelitian ini disebabkan karena dari responden yang pemanfaatan PKPR rendah lebih banyak yang mengatakan tidak tersedia tenaga pelayanan PKPR.

\section{Pengaruh Ketersediaan Fasilitas Kesehatan di Puskesmas dengan Pemanfaatan PKPR \\ Ketersediaan fasilitas kesehatan} dalam penelitian ini merupakan penilaian responden terhadap ketersediaan dan keberadaan sarana PKPR. Berdasarkan hasil penelitian ini menunjukkan bahwa sebagian besar responden menilai tidak tersedia terhadap ketersediaan fasilitas kesehatan di puskesmas sebesar $67,7 \%$ (65 responden). Hasil uji statistik chi-square terhadap ketersediaan fasilitas kesehatan di puskesmas dengan pemanfaatan pelayanan kesehatan peduli remaja (PKPR) oleh remaja sekolah (15-19 tahun) di wilayah kerja puskesmas Tlogosari, Tamanan dan Maesan Kabupaten Bondowoso tahun 2019 pada penelitian ini menunjukkan bahwa kedua variabel tersebut terdapat pengaruh yang bermakna karena $p$-value sebesar 0,000 atau $p<$ 0,05 .

Hasil penelitian ini sesuai dengan teori menurut Anderson (1974) (dalam Retnaningsih, 2013:68) yang menyatakan bahwa fasilitas pelayanan kesehatan merupakan faktor yang mendahului perilaku untuk menunjang motivasi atau aspirasi dapat terwujud serta sumber daya untuk menunjang perilaku kesehatan. Fasilitas jasa akan berpengaruh terhadap persepsi konsumen. Menurut Azwar (2010) menyatakan bahwa pelayanan yang baik adalah pelayanan kesehatan yang tersedia di masyarakat (acceptable), artinya semua jenis pelayanan kesehatan yang dibutuhkan masyarakat ditemukan serta keberadaannya dalam masyarakat adalah ada pada tiap saat dibutuhkan.

Berdasarkan hasil penyebaran angket/kuesioner sebagian besar responden yang tingkat pemanfaatan PKPR rendah lebih banyak yang mengatakan tidak tersedia fasilitas pelayanan PKPR dibandingkan dengan yang tersedia fasilitas kesehatan. Sebaliknya, persentase responden dengan tingkat pemanfataan PKPR tinggi lebih besar terdapat pada responden yang tersedia fasilitas kesehatan dibandingkan dengan fasilitas kesehatan tidak tersedia. Sehingga hal ini menyababkan terdapat pengaruh antara ketersediaan fasilitas kesehatan dengan pemanfaatan PKPR oleh remaja sekolah (15-19 tahun) pada penelitian ini.

\section{Pengaruh Kompetensi Tenaga Kesehatan dengan Pemanfataan PKPR \\ Kompetensi tenaga kesehatan dalam} penelitian ini merupakan penilaian responden terhadap pelayanan tenaga kesehatan di puskesmas yang dapat memberikan pelayanan kesehatan peduli remaja yang dibutuhkan remaja yang dilihat dari sikap, keramahan, pengetahuan, keterampilan, kemampuan dan kejelasan informasi yang diberikan melalui pendidikan formal sehingga dapat memberikan pelayanan sesuai kewenangnya. Berdasarkan hasil penelitian ini menunjukkan bahwa sebagian banyak responden menilai tenaga kesehatan pada kategori kompeten sebesar $59,4 \%$ (57 responden). Hasil uji statistik chi-square terhadap kompetensi tenaga kesehatan dengan pemanfaatan pelayanan kesehatan peduli remaja (PKPR) oleh remaja sekolah 
(15-19 tahun) di wilayah kerja Puskesmas Tlogosari, Tamanan dan Maesan Kabupaten Bondowoso tahun 2019 pada penelitian ini menunjukkan bahwa kedua variabel tersebut terdapat pengaruh yang bermakna karena $p$-value sebesar 0,002 atau $p<0,05$.

Hasil ini sejalan dengan penelitian Kristina (2017:65) menyatakan bahwa petugas kurang bersahabat dalam melakukan pelayanan sebesar $97,2 \%$ dan terdapat hubungan yang signifikan antara petugas dalam melakukan pelayanan dengan pemanfaatan pelayanan kesehatan reproduksi remaja di Kota Jayapura ( $p=$ 0,043 ). Hal ini karena petugas memandang rendah remaja, tidak mendengarkan keluhan remaja dengan penuh perhatian, memarahi keadaan remaja, dan petugas tidak dapat menjaga rahasia. Sehingga menyebabkan remaja tidak datang ke pelayanan PKPR, karena takut masalahnya diketahui orang lain. Namun dalam penelitian ini responden menilai kompetensi tenaga kesehatan cukup kompeten, yaitu 34 responden setuju bahwa petugas memiliki pengetahuan yang memadai mengenai masalah yang dihadapi remaja, 28 remaja setuju bahwa petugas terampil dalam memberikan pelayanan, 37 remaja setuju bahwa petugas mendengar keluhan dengan baik, 32 remaja setuju bahwa petugas selalu bersikap ramah dan bersahabat, serta 31 remaja setuju bahwa petugas mampu berkomunikasi dengan baik yang mudah dimengerti.

\section{Pengaruh Waktu/Kecepatan Pelayanan dengan Pemanfaatan PKPR}

Waktu/kecepatan pelayanan dalam penelitian ini merupakan waktu minimal yang digunakan untuk melayani pasien dari awal masuk tempat pendaftaran sampai dengan pulang. Berdasarkan hasil penelitian ini menunjukkan bahwa sebagian besar responden menilai kurang baik terhadap waktu/kecepatan pelayanan sebesar $71,9 \%$ (69 responden). Hasil uji statistik fisher's exact test terhadap waktu/kecepatan pelayanan dengan pemanfaatan pelayanan kesehatan peduli remaja (PKPR) oleh remaja di wilayah kerja Puskesmas Tlogosari, Tamanan dan Maesan Kabupaten Bondowoso tahun 2019 pada penelitian ini menunjukkan bahwa kedua variabel tersebut terdapat pengaruh yang bermakna karena $p$-value sebesar 0,012 atau $p<0,05$. Hal ini karena keadaan di lapangan menunjukkan waktu tunggu kurang dari 60 menit, waktu pemeriksaan kurang dari 15 menit, dan waktu untuk administrasi dan pengambilan obat 15 menit.

Kemenkes Nomor 129 tahun 2008 menyatakan bahwa, standar pelayanan minimal di rawat jalan ialah kurang dari 60 menit yaitu waktu yang dipergunakan pasien mulai pendaftaran sampai dengan dilayani dokter dengan waktu kurang dari 1 jam. Namun waktu tunggu berbeda setiap rumah sakit atau puskesmas. Teori Anderson (1960), (dalam Priyoto, 2014:246-251) juga menyatakan bahwa, ketika harga pelayanan kesehatan diminimalkan maka seseorang akan mempertimbangkan penggunaan waktu seperti jauh dekatnya dengan tempat pelayanan kesehatan atau lama waktu tunggu sebelum mendapat pelayanan kesehatan juga akan mendapat perhatian dari konsumen.

\section{Pengaruh Penilaian Keadaan Kesehatan yang dirasakan oleh Individu dengan Pemanfaatan PKPR}

Penilaian keadaan kesehatan yang dirasakan oleh individu dalam penelitian ini merupakan penilaian seseorang terhadap konsep penyakit, tindakan yang dilakukan jika sakit dan kebutuhan segera untuk memanfaatkan pelayanan kesehatan. Berdasarkan hasil penelitian ini menunjukkan bahwa mayoritas responden menilai baik terhadap kesehatan yang dirasakan sebesar 94,8\% (91 responden). Hasil ini sejalan dengan teori Health Belief Model, ketika seseorang persepsinya serius terhadap kondisi dirinya maka akan mendorong untuk bertindak mencari pengobatan (Priyoto, 2014:250). Seseorang akan mengunjungi pelayanan kesehatan jika merasa kondisi kesehatannya sudah jauh menurun, namun juga ada yang sudah mengalami penurunan kesehatan tetapi tetap tidak ingin mengunjungi pelayanan kesehatan yang tersedia. Seseorang yang memiliki penyakit serius lebih banyak yang memanfaatkan pelayanan kesehatan dibandingkan yang tidak memiliki penyakit serius.

Hasil uji statistik fisher's exact test terhadap penilaian keadaan kesehatan yang dirasakan oleh individu dengan pemanfaatan pelayanan kesehatan peduli remaja (PKPR) oleh remaja sekolah (15-17 tahun) di wilayah kerja Puskesmas 
Karina, et al, Faktor Yang Mempengaruhi Pemanfaatan Pelayanan Kesehatan ......

Tlogosari, Tamanan dan Maesan Kabupaten Bondowoso tahun 2019 pada penelitian ini menunjukkan bahwa kedua variabel tersebut tidak terdapat pengaruh yang bermakna karena $p$-value sebesar 1,000 atau $p>0,05$. Hasil penelitian ini sejalan dengan penelitian Kristina (2017:65) yang menyatakan tidak terdapat hubungan antara kebutuhan dengan pemanfaatan pelayanan kesehatan reproduksi remaja di Kota Jayapura $(p=$ $0,104)$. Kebutuhan merupakan dasar dan stimulus langsung untuk menggunakan pelayanan kesehatan, bilamana tingkat predisposisi dan enabling itu ada. Pencarian pengobatan atau pemanfaatan pelayanan kesehatan dapat terwujud dalam suatu tindakann apabila itu dirasakan sebagai kebutuhan (Notoatmodjo, 2014:108).

\section{Analisis Multivariat/Faktor yang Paling Berpengaruh terhadap Pemanfaatan Pelayanan Kesehatan Peduli Remaja (PKPR)}

Dalam penelitian ini, variabel yang diprediksi menjadi faktor yang mempengaruhi pemanfaatan PKPR oleh remaja sekolah (15-19 tahun) di wilayah kerja puskesmas Kabupaten Bondowoso tahun 2019 adalah ketersediaan tenaga kesehatan, ketersediaan fasilitas kesehatan, kompetensi tenaga kesehatan, dan waktu/kecepatan pelayanan karena memiliki $p<0,25$. Metode yang digunakan dalam regresi logistik adalah metode forward stepwise (likelihood ratio). Metode forward stepwise (likelihood ratio) akan memasukkan variabel bebas yang memiliki nilai (score) besar dan nilai $p$-value $<0,05$ (Sarwono, 2013:147). Dengan metode ini didapat variabel yang mempengaruhi pemanfaatan PKPR oleh remaja sekolah (15-19 tahun) adalah ketersediaan fasilitas kesehatan dan kompetensi tenaga kesehatan. Nilai OR terbesar ialah nilai OR kompetensi tenaga kesehatan dengan kategori kurang kompeten yaitu sebesar 6,1 yang berarti bahwa tenaga kesehatan kurang kompeten berisiko 6,1 kali lipat untuk hasil pemanfaatan PKPR rendah.

\section{SIMPULAN DAN SARAN}

\section{Simpulan}

a. Tidak terdapat pengaruh karakteristik predisposisi (umur, jenis kelamin pendidikan, pengetahuan) terhadap pemanfaatan PKPR oleh remaja sekolah.

b. Tidak terdapat pengaruh karakteristik pemungkin/enabling (asuransi kesehatan dan aksesibilitas menuju pelayanan kesehatan mudah) terhadap pemanfaatan PKPR oleh remaja sekolah Serta terdapat pengaruh karakteristik pemungkin/enabling (ketersediaan tenaga kesehatan dan fasilitas kesehatan, kompetensi tenaga kesehatan, waktu/pelayanan kesehatan) terhadap pemanfaatan PKPR oleh remaja sekolah.

c. Tidak terdapat pengaruh faktor kebutuhan (keadaan kesehatan ) terhadap pemanfaatan PKPR oleh remaja sekolah.

d. Faktor-faktor yang paling berpengaruh ialah ketersedian fasilitas kesehatan dan kompetensi tenaga kesehatan.

\section{Saran}

a. Dinas Kesehatan

Perlu menambah tenaga kesehatan dan fasilitas khusus PKPR di beberapa puskesmas, melakukan sosialisasi tentang PKPR di beberapa forum dan mitra, seperti LSM, tokoh masyarakat, kelompok masyarakat, karang taruna maupun perguruan tinggi untuk meningkatkan kerjasama dan dukungan dalam menyelenggarakan PKPR dan melakukan supervisi dan menilai kembali pencapain SN-PKPR Puskesmas yang sebelumnya sudah dinilai dan dipantau.

b. Puskesmas

Perlu adanya penambahan tenaga kesehatan untuk mengelola program PKPR, karena tenaga kesehatan yang ada masih merangkap tugas, menyediakan ruang PKPR atau konsultasi yang baik dan terpisah dengan pelayanan yang lain, membuat jadwal pelayanan khusus bagi remaja di luar jam sekolah dan jadwal jaga petugas PKPR supaya dapat memberikan pelayanan kesehatan yang lebih tepat waktu kepada remaja yang membutuhkan, pelatihan keterampilan praktis melalui teknik konseling dan public speaking secara berkala minimal 1 tahun sekali bagi petugas PKPR puskemas dalam mengelola remaja, dan meningkatkan kegiatan PKPR di dalam maupun luar gedung dengan meningkatkan volume kegiatan, hal ini dikarenakan rendahnya kesadaran remaja akan pemanfaatan PKPR. 
Karina, et al, Faktor Yang Mempengaruhi Pemanfaatan Pelayanan Kesehatan ......

c. Masyarakat

Remaja sebaiknya memaksimalkan pemanfaatan kegiatan yang dilaksanakan oleh PKPR baik di dalam maupun di luar puskesmas yang tidak hanya sebatas pelayanan medis (berobat ketika sakit). Hal ini bertujuan agar mencegah supaya tidak sampai jatuh sakit atau ada permasalahan.

d. Peneliti selanjutnya

Perlu melakukan penelitian terkait perspektif tenaga kesehatan terhadap penyelenggaran PKPR atau evaluasi 5 aspek penyelenggaran PKPR di puskesmas.

\section{Daftar Pustaka}

[1] Sarwono WS. 2015. Psikologi Remaja. Jakarta: PT Raja Grafindo Persada.

[2] Kementerian Kesehatan RI. 2015. Infodatin: Pusat Data dan Informasi. Jakarta: Kementerian Kesehatan RI.

[3] World Health Organization. 2014. Adolescent Friendly Health Service, An Agenda for Change.

[4] Kementerian Kesehatan RI. 2019. Data dan Informasi Profil Kesehatan Indonesia 2018. Jakarta: Kementerian Kesehatan RI.

[5] BKKBN; BPS; Kementerian Kesehatan. 2018. Survei Demografi dan Kesehatan Indonesia 2017: Kesehatan Reproduksi Remaja. Jakarta: USAID.

[6] Dinas Kesehatan Kabupaten Bondowoso. 2019. Data Pemanfaatan Pelayanan Kesehatan Peduli Remaja (PKPR). Bondowoso: Dinas Kesehatan Kabupaten Bondowoso.

[7] Kementerian Kesehatan RI. 2014. Pedoman Standar Nasional Pelayanan Kesehatan Peduli Remaja (PKPR). Jakarta: irektorat Jenderal Bina Gizi dan Kesehatan Ibu dan Anak, Kementerian Kesehatan Republik Indonesia.

[8] Dinas Kesehatan Kabupaten Bondowoso. 2018. Data Primer Pelaksanaan Pelayanan Kesehatan Peduli Remaja (PKPR). Bondowoso: Dinas Kesehatan Kabupaten Bondowoso.
[9] Kementerian Kesehatan, Direktur Jenderal P2PI, dr. H.M. Subuh, MPPM. (2016, Mei 18). Dipetik Oktober 30, 2018.

[10] Priyoto. 2014. Teori Sikap dan Perilaku Dalam Kesehatan. Yogyakarta: Nuha Medika.

[11] Laili AN, Emmy R, dan Syamsulhuda BM. Faktor-Faktor yang Berhubungan dengan Praktik Pemanfaatan Pelayanan Kesehatan Peduli Remaja (PKPR) oleh Remaja Wilayah Kerja Puskesmas Bandarharjo Kota Semarang. Jurnal Kesehatan Masyarakat (e-journal). 2019; 7(1): 421-429. [Diakses pada 19 September 2019].

[12] Winangsih R. 2015. Persepsi Remaja Terhadap Pelayanan Kesehatan Peduli Remaja di Wilayah Puskesmas Kuta Selatan. Thesis. Denpasar: Program Pascasarjana IImu Kesehatan Masyarakat.

[13] Muzaham F. 2007. Memperkenalkan Sosiologi Kesehatan. Jakarta: Universitas Indonesia Press.

[14] Kristina Y. Faktor-faktor yang Mempengaruhi Pemanfaatan Pelayanan Kesehatan Reproduksi Remaja di Kota Jayapura. Jurnal Biologi Papua. 2017; 9(2): 63-73. [24 September 2019].

[15] Ruwaida dan Nurmisih. Faktor-faktor yang Berhubungan dengan Pemanfaatan Pelayanan Kesehatan Reproduksi oleh Remaja di SMPN 19 Wilayah Kerja Puskesmas Aur Duri Kota Jambi. Jurnal Bahana Kesehatan Masyarakat. 2017; 1(2): 114-120. [25 September 2019].

[16] Azwar A. 2010. Pengantar Administrasi Kesehatan. Jakarta: Bina Rupa Aksara Publisher.

[17] Suhariati. 2010. Analisis Faktor Yang Mempengaruhi Implementasi Program Pelayanan Kesehatan Peduli Remaja (PKPR) di Puskesmas Wilayah Kabupaten Kediri. Universitas diponegoro. Program magister IKM.

[18] Retnaningsih E. 2013. Akses Layanan Kesehatan. Jakarta: Rajawali Pers.

[19] Notoatmodjo, S. 2014. IImu Perilaku Kesehatan Cetakan Ke-2. Jakarta: Rineka Cipta. 